\title{
Impact of Macroeconomic Variables on Stock Price Index: Evidence from Vietnam Stock Market
}

\author{
Thi Minh Huong Le J $^{1,2^{*}} \quad$ Jian Zhihong $^{1} \quad$ Zhican $Z^{1}{ }^{1}$ \\ 1.School of Economics, Huazhong University of Science and Technology; \\ Luoyu Road 1037, Wuhan, Hubei, China \\ 2. Da Nang Architecture University, 566 Nui Thanh, Da Nang, Vietnam
}

\begin{abstract}
Vietnam stock market after nearly 20 years of operation has undergone many ups and downs. In addition to the contribution to the development of the national economy, the Vietnam Stock market still has some certain shortcomings. Goods on the market have increased in size, quantity, and categories but not much of diversity. The potential risks due to many different causes, always hurt investors. Therefore, the study of Macroeconomic factors affecting the volatility of stock indexes has been paid special attention by society. Research results show that, in the long term, the VNI stock price index is affected by the oil price, money supply, interest rate, SJC gold price, and exchange rate. In the short term, the stock price index has a causal relationship with oil prices, interest rates, and the M2 money supply. When there are impacts of market shocks, short-term corrections affect extremely slow to the long-term balance.
\end{abstract}

Keywords: macroeconomic factors, VNI, Vietnam stock market, ECM, VAR

DOI: $10.7176 /$ RJFA/10-12-04

Publication date:June $30^{\text {th }} 2019$

\section{Introduction}

In the structure of the financial market, the stock market plays an essential role in providing an additional channel of long-term capital mobilization for the economy (Mishkin, 2004). People often compare securities price indexes such as mirrors to reflect the market health, through which we partly understand the business performance of corporations. The stock price index is a quite sensitive indicator in the volatile macroeconomic environment. In general, many different causes affect the volatility of the stock price index. In particular, the analysis of macroeconomic factors is an essential requirement of the primary analysis method when assessing Vietnam's stock market in the current complicated period.

Vietnam stock market was born after several decades of Asian countries and after hundreds of years of developed countries market. However, after nearly 20 years since its inception (commencing operations on July 20, 2000), the Vietnam Stock market has gone through many ups and downs. Although there are many different indicators such as VN index, HNX index, VN index - 30, Upcom index, Baoviet index, etc., the VN index is always considered the most critical and typical stock price index when evaluating the overall volatility of Vietnam's stock market. At one point, VNI had a fantastic breakthrough, hitting 1,170.67 points (March 12, 2007), partly reflecting the overheating of the market. Besides contributions to the development of the national economy, the Vietnam stock market still has certain limitations. Commodities on the Vietnam stock market have increased in size, quantity, and types but not much of diversity. There are only five trading sessions a week, two times a day. Besides, the potential risks due to many different causes on the stock market always hurt investors. Therefore, the study of factors affecting the volatility of the stock index has always been of particular interest to investors and society. The stock market factors found in empirical studies have been published to include various factors stemming from macroeconomic factors and from the company itself. The study mainly focused on reviewing and analyzing macroeconomic factors affecting the stock market.

Macroeconomic Variables are indicators that signal the current trends in the economy, like, the gross domestic product, rate of employment, consumer price index, the balance of payments, broad money supply, lending interest rate, household consumption, etc.

\section{Literature review}

Over the years, there has been a lot of research carried out on the impact of macroeconomic factors on the stock market. (Perera and Silva, 2018) systematized the review of theories through 58 studies that have been published in prestigious journals. According to the survey, three critical approaches have been discovered: dividend discount model, price difference theory, and effective market model. Research shows that often past studies often use only the national data of each country, little use of global macroeconomic data, moreover the analytical testing procedures are simple, therefore, does not reflect the impact of macro factors on the stock market. The study offers a comprehensive view by selecting materials from research in this area.

In recent years, several other studies have been found using the OLS regression model to analyze factors. Accurately, (Hanif and Bhatti, 2019) presented the correlation, unit solution, OLS regression, and Granger test of 
Variables. In particular, the author has collected eight macro factors in Pakistan, including exchange rates, interest rates, money supply, inflation, industrial production, gold prices, and remittances of Islamic and market stock markets. The research period is from July 2011 to October 2016. Research results indicate that there is no short-term cointegration relationship between the two types of stock indexes. Industrial production and money supply have a substantial impact on securities prices, while gold prices and exchange rates have a negligible effect on the domestic stock index.

In addition to the OLS method, co-integration testing through the ARDL model, and VECM techniques are also used (Akbar, Rauf and Chaudhry, 2019). The author studied in the Pakistani stock market during the period from January 1992 to December 2012 with seven independent Variables included in the model including Tax, inflation, money supply, exchange rate, overall Domestic savings, gross domestic product, and nominal interest rates. Corresponding to the different lags will have a positive or negative impact on the stock market performance in the current month or one, or two months later.

VECM model is also used to study in adjusting errors on the impact of macro factors on the Indian stock market. With this study (Kaur and Singh, 2019) used factors including exports, imports, gold prices, and Mcxcomdex impact on the Nifty index stock index. The results show that these Variables have no long-term relationship. The author continues to use the VAR model and detects short-term relationships that had developed.

When studying major stock markets in the US and Europe including DAX30 (Germany), IBEX35 (Spain), CAC40 (France), MIB30 (Italy), FTSE100 (United Kingdom) and S \& P500 (United States), the author has used some important macroeconomic factors such as gross domestic product, consumer price index, industrial production index and unemployment (Francisco, Ana and Alberto, 2019). Research shows that depending on the stage of the study, the economy, sample size, as well as research methods, the results may Covariance. The results of this study indicate that unemployment has a significant negative impact, whereas the domestic gross domestic product, industrial production index has a positive effect on the international stock market.

In another paper, the authors studied a macroeconomic model with endogenous Variables and heterogeneous expectations of the Weidlich-Haag-Lux method improved by Franke (2012). With this study, the authors focus on the impact of stock prices on macroeconomic activity through the Brainard-Tobin q model, which is quite simple because the price of goods is assumed to be constant (Peter Flaschel, Matthieu Charpe, Giorgos Galanis, 2017).

Another study analyzes the stock market's risk exposure through market beta. In particular, the MIDAS frame model used as the basis of weighted average estimates of high frequencies. The well-known portfolio is used to show a correlation with macroeconomic factors. The conclusion from the study suggests that the difference between the two beta effects may be relevant for factor valuation (González et al., 2019).

The fact that the profitability of stocks in the Arab market generally does not follow the normal distribution, so the ARDL model research method is implemented at Jordanian by (Mohamed and Ahmed, 2014). In this model, the author used annual data of 218 listed companies in the period of 1976 to 2016, using six essential macroeconomic factors, including Industrial production, interest rate, money supply., inflation, gross domestic product, and import prices. Research results indicate that the money supply has a positive impact on stock returns. Meanwhile, import prices are negative, but finding new markets outside the traditional markets such as the Gulf, or Iraq is a requirement for the Jordanian market. This requires a lot of policies to support the local industry with global product standards.

Another way of looking at the impact of these factors on the stock market is the impact of market shocks (Yang et al., 2018). With the application of three Variables SVAR model on inflation, output growth, and stock returns. The author collected and analyzed data from January 2003 to September 2015 in the Korean stock market. The author's new finding demonstrates that economic shocks on demand fluctuations are much larger than shocks on supply fluctuations. Also, the author also examined the 5 - Variable - model when adding the exchange rate and interest rate Variables to increase the significance level for the model, as well as confirming the same results with previous studies.

Next, we are interested in empirical studies that have done regarding emerging stock markets in Vietnam. One of the studies developed by (Hussainey and Khanh Ngoc, 2009) provided evidence of factors such as domestic manufacturing, money market, and stock prices in Vietnam that have a confidential relationship. In particular, the author stressed the foundation of US macroeconomic factors that significantly impacted Vietnam's stock market. Another study, (Vinh, 2014) studied in Vietnam stock market to evaluate US stock index S \& P500, exchange rate, domestic gold price, and crude oil price with the global financial crisis. Research had shown that the period before and after the crisis, the US and Vietnam stock indexes had all interrelated relations. However, with exchange rates, gold prices, and crude oil prices only have a relationship with stock price index after the crisis period. Acquiring past results and continuing to apply on the Vietnamese stock market by finding the gap left by previous studies. Specifically, the paper will analyze and apply the OLS model, VAR model, and ECM error correction model, co-integration test, and stock price forecast. The fundamental macroeconomic factors continue to use as exchange rates. Besides, the author will supplement the impact of macro factors on Vietnam's 
stock market comprehensively during the past ten years after the global economic crisis to date. At the same time, the article further considers the relationship between the domestic gold price (SJC), world oil price, consumer price index, and money supply to the Vietnam stock market.

\section{Data and methodology \\ 3.1 Data description}

The study focused on analyzing six factors affecting VNI, namely: SJC gold price, world oil price, M2 money supply, interest rate, exchange rate, and consumer price index. Research data were collected over ten years from January 2009 to December 2018.

- VNI stock price index:

VNI was the first stock index on HOSE in July 2000 and is considered one of the most representative indicators for the whole market. With the capitalization scale, operating time, several listed companies, as well as a large number of investors, participating, so VNI is more representative than some other indicators like HNX index, VNI 30, SSI index, BaoViet index, etc. The stock price index Variable is taken in units of points and is the closing price of the last trading day of each month. Data collected from the website of the State Securities Commission. Most companies with stocks listed on HOSE are companies with large capital sources, healthy financial situation, effective and transparent business operations, and disclosure of information according to regulations. Periodically, HOSE will conduct delisting procedures for certain companies on the floor. These are the indications that VNI has a good ability to represent the Vietnam stock market. Data of VNI Variables collected from Ho Chi Minh City Stock Exchange. https://www.hsx.vn/

\section{- Gold price Variable:}

Like all precious metals, gold is calculated by troy weight and in grams. When it combined with other metals, the term kara or karat is used to indicate the amount of gold present, with 24 karas being pure gold and lower ratios represented by lower numbers. A decimal number can also express the purity of a gold coin or gold coin from 0 to 1 , called the golden age in parts per thousand, as 0.995 is very pure. Gold prices determined by trading in gold and derivative markets, but a process called Gold valuation in London, which began in September 1919 provides a benchmark for the industry. Later on, the same valuation was introduced in 1968 to provide gold prices when US markets opened. The topic of consideration on the Vietnam stock market and gold price collected according to the selling price of 1 tael SJC gold, the unit of millions of dong calculated on the last trading day of each month. Gold price data collected from the Saigon Liberation Online website. http://www.sggp.org.vn/

\section{- Oil prices:}

The oil industry divides "crude oil" according to the area in which it originates (e.g. "West Texas Intermediate" (WTI) or "Brent"), usually by weight and its relative viscosity (light, average or heavy). Crude oil also classified as "sweet" or "sour" depending on the level of sulfur. Sweet crude oil contains $0.5 \%$ sulfur or less, and sour crude contains about $1 \%$ sulfur and takes more steps to produce it according to current parameters. In general, the heavier the crude oil, the greater it's sulfur content. Excess sulfur is removed from crude oil during refining because sulfur oxide discharged into the air during oil combustion is a major contaminant. The barrel is the unit used to measure the volume of crude oil in trade. One can hold 42 US gallons 158.9873 liters, 07 barrels (barrels) of oil 1.113 tons, 1 gallon in the US $3.785 \mathrm{~cm}^{3} \sim 3.785$ liters. Collected data on world oil prices collected by the average monthly value of WTI crude oil traded on the NYSE exchange. (https://www.investing.com/currencies/wti-usd-historical-data).

\section{- Money supply M2:}

The money supply is the amount of money provided to satisfy the payment and reserve needs of entities in the economy. The money supply must correspond to the demand for money. The shortage or surplus of money supply against demand can all lead to negative impacts on the economy. Since the level of financial market development varies from country to country and changes over time, the composition of the measurements mentioned above maybe covariance across countries and change over time. For example, The US Federal Reserve (Fed) also added traveler's checks and other forms of deposits that can be issued to other checks on M1 and M2 measurements they split term deposits into term deposits. In small quantities, leaving M2 with long term deposits then moving to M3 and adding M2 money market deposit accounts, shares of money market mutual funds (not organized). Vietnam added M2 commercial bank bills. The selection of a precise measurement of the actual amount of money will base on the measurement of the amount of money that helps to predict the best economic Variables that the currency has as much impact as the inflation rate, business cycle. Countries often use M1 or M2 and Vietnam measurements using M2 measurement. Money supply data collected from the Vietnam Securities website.

(https://finance.vietstock.vn/).

\section{- Interest rate Variable:}

The rate by which the borrower pays for the money they borrow from a lender. Interest rate targets are an 
important tool of monetary policy and are taken into account when dealing with Variables such as investment, consumer price index, and unemployment. Central banks or reserve banks of countries, in general, tend to reduce interest rates when they want to increase investment and consumption in the country's economy. However, a low-interest rate as a macroeconomic policy can be risky and can lead to the creation of an economic bubble in which a large amount of investment poured into the real estate and stock market. The data on the interest rate used by the project calculated according to the percentage of refinancing interest rates prescribed by the State Bank and published on the State Bank Website (https://www.sbv.gov.vn/).

\section{- Exchange rate Variable:}

The exchange rate is the rate at which a currency will exchange for another currency. It is also considered the currency price of a country expressed by another currency. Comparing to other currencies, the USD most commonly used and used by most businesses in international payment contracts. Exchange rate data collected from the website of the State Bank, taken from the exchange rate between USD and VND, this Variable represents the foreign exchange market. (https://www.sbv.gov.vn/).

\section{- Consumer price index Variable:}

This indicator is used to reflect the level of inflation, i.e., the increase over time of the general price level of the economy. In an economy, inflation is a loss of market value or a decrease in the purchasing power of the currency. When compared to other economies, inflation is the currency devaluation of a currency compared to other currencies. Usually, in the first case, it is understood that the inflation of the monetary unit within the economy of a country, in the second case, it is understood as inflation of a currency in the global market school. The scope of these two components is still a controversial topic among macroeconomists. In contrast to inflation is deflation. The level of inflation is zero, or a small positive index is called "price stability." Data, The consumer price index, is taken from the percentage change in CPI of each month compared to the previous month and taken from the General Statistics Office's data source (https://www.gso.gov.vn/).

\subsection{Methodology}

This study uses a quantitative analysis method with a monthly time series of 120 observations from January 2009 to December 2018 as well as uses a due model (Hanif and Bhatti, 2019) to propose. On time series data, research rescue using additional DF test method is ADF (Augmented Dickey-Fuller test) for corpse stationery, Cointegrated Test by the technique of Johansen and Juselius to consider whether there exist. Long-term relationships between the variables studied to assist in selecting the use of the least squares multivariate regression analysis method (OLS) to determine the Variation Macroeconomic factors in the long term and using the VAR method to determine the optimal lag. Granger Causality Test test to assess the degree of influence of short-term variables; while tissue Error Correction Model (ECM) will help track the adjustment process of Vietnam stock market from the state Short term towards long-term balance.

The research model looks like this:

$\mathrm{VNI}_{\mathrm{i}}=\beta_{1}+\beta_{2} \mathrm{SJC}+\beta_{3} \mathrm{OIL}+\beta_{4} \mathrm{M} 2+\beta_{5} \mathrm{IR}+\beta_{6} \mathrm{EX}+\beta_{6} \mathrm{CPI}+\mathrm{U}_{\mathrm{i}}$

$\left(\mathbf{Y}=\boldsymbol{\beta}_{1}+\boldsymbol{\beta}_{2} \mathbf{X}_{2}+\beta_{3} X_{3}+\beta_{4} X_{4}+\beta_{5} X_{5}+\beta_{6} X_{6}+\beta_{7} X_{7}+U_{i}\right)$

Where:

Y: (Dependent Variable) is a stock price index of VNI

$\mathrm{X}$ : (Independent Variable) are Variables of SJC gold price, world oil price, M2 money supply, Interest rate, exchange rate, and Consumer price index (representing inflation).

Ui: As residuals, is assumed to be random 
Table 1. Expected signs of regression coefficients in the model

\begin{tabular}{|c|c|c|c|c|}
\hline Variables & Unit & Coefficient & $\begin{array}{l}\text { Expected } \\
\text { sign }\end{array}$ & Previous studies \\
\hline $\begin{array}{c}\text { VNI } \\
\text { (Vietnam stock price index) }\end{array}$ & Point & & & \\
\hline \multirow{2}{*}{$\begin{array}{c}\text { SJC } \\
\text { (Domestic Gold price) }\end{array}$} & \multirow{2}{*}{$\begin{array}{c}\text { Million } \\
\text { VND/tael }\end{array}$} & \multirow[t]{2}{*}{$\boldsymbol{\beta}_{2}$} & + & (Kaur and Singh, 2019) \\
\hline & & & - & $\begin{array}{l}\text { (Hanif and Bhatti, 2019), (Do, Mcaleer } \\
\text { and Sriboonchitta, 2009), (Smith, } \\
\text { 2001), (Gokmenoglu, 2015) }\end{array}$ \\
\hline \multirow[t]{2}{*}{$\begin{array}{c}\text { Oil } \\
\text { (Price of oil) }\end{array}$} & \multirow[t]{2}{*}{ USD/barrel } & \multirow[t]{2}{*}{$\beta_{3}$} & + & $\begin{array}{l}\text { (Chittedi, 2012), (Kumar and Narayan, } \\
\text { 2010), (Tursoy and Faisal, 2017) }\end{array}$ \\
\hline & & & - & (Gokmenoglu, 2015) \\
\hline \multirow[t]{2}{*}{$\begin{array}{c}\text { (M2) } \\
\text { Money Supply }\end{array}$} & \multirow[t]{2}{*}{$\begin{array}{l}\text { Billion } \\
\text { VND }\end{array}$} & \multirow[t]{2}{*}{$\boldsymbol{\beta}_{4}$} & + & $\begin{array}{l}\text { (Akbar, Rauf and Chaudhry, 2019), } \\
\text { (Mohamed and Ahmed, 2014), }\end{array}$ \\
\hline & & & - & (Hanif and Bhatti, 2019) \\
\hline \multirow[t]{2}{*}{$\begin{array}{c}\text { IR } \\
\text { (Interest rate) }\end{array}$} & \multirow[t]{2}{*}{$\%$} & \multirow[t]{2}{*}{$\beta_{5}$} & + & $\begin{array}{l}\text { (Akbar, Rauf and Chaudhry, 2019), } \\
\text { (Hussainey and Khanh Ngoc, 2009) }\end{array}$ \\
\hline & & & - & (Hanif and Bhatti, 2019) \\
\hline \multirow{2}{*}{$\begin{array}{c}\mathrm{EX} \\
\text { (Exchange rate) }\end{array}$} & \multirow[t]{2}{*}{ USD/VND } & \multirow[t]{2}{*}{$\beta_{6}$} & + & (Hanif and Bhatti, 2019) \\
\hline & & & - & $\begin{array}{l}\text { (Akbar, Rauf and Chaudhry, 2019), } \\
\text { (Wei et al., 2019), (Sadeghi, 2018) }\end{array}$ \\
\hline \multirow[t]{3}{*}{$\begin{array}{c}\text { CPI } \\
\text { (Consumer price index) }\end{array}$} & \multirow[t]{3}{*}{$\%$} & \multirow[t]{3}{*}{$\boldsymbol{\beta}_{7}$} & $+/-$ & $\begin{array}{l}\text { (Kaur and Singh, 2019), (Yang et al., } \\
\text { 2018) }\end{array}$ \\
\hline & & & + & $\begin{array}{l}\text { (Hanif and Bhatti, 2019), (Francisco, } \\
\text { Ana and Alberto, 2019), }\end{array}$ \\
\hline & & & - & $\begin{array}{l}\text { (Akbar, Rauf and Chaudhry, 2019), } \\
\text { (Mohamed and Ahmed, 2014) }\end{array}$ \\
\hline
\end{tabular}

\section{Result}

\subsection{Descriptive statistics}

The descriptive statistics table is a summary report on the value of observed Variables included in the model in the period $2009-2018$.

Table 2. Descriptive statistics

\begin{tabular}{|l|c|c|c|c|c|c|c|}
\hline & VNI & SJC & OIL & M2 & IR & EX & CPI \\
\hline Mean & 584.3180 & 35389.58 & 73.33517 & 4718281. & 7.900000 & 21140.47 & 1.504417 \\
\hline Median & 548.9550 & 36175.00 & 73.97000 & 4484895. & 6.500000 & 21116.25 & 1.355000 \\
\hline Maximum & 1174.460 & 47420.00 & 113.7300 & 9121583. & 15.00000 & 23345.50 & 4.320000 \\
\hline Minimum & 245.7400 & 18050.00 & 33.75000 & 1561466. & 5.000000 & 17480.50 & 0.470000 \\
\hline Std. Dev. & 188.5892 & 6425.453 & 21.88156 & 2288264. & 2.589044 & 1509.193 & 0.645694 \\
\hline Skewness & 1.186920 & -0.647287 & -0.044907 & 0.386334 & 1.615574 & -0.778428 & 1.491046 \\
\hline Kurtosis & 4.026147 & 3.637677 & 1.642194 & 1.924255 & 4.515269 & 2.960277 & 5.832931 \\
\hline Jarque-Bera & 33.44049 & 10.41276 & 9.258515 & 8.771220 & 63.68181 & 12.12690 & 84.59185 \\
\hline Probability & 0.000000 & 0.005481 & 0.009762 & 0.012455 & 0.000000 & 0.002326 & 0.000000 \\
\hline Sum & 70118.16 & 4246750. & 8800.220 & $5.66 \mathrm{E}+08$ & 948.0000 & 2536856. & 180.5300 \\
\hline Sum Sq. Dev. & 4232340. & $4.91 \mathrm{E}+09$ & 56977.50 & $6.23 \mathrm{E}+14$ & 797.6750 & $2.71 \mathrm{E}+08$ & 49.61356 \\
\hline Observations & 120 & 120 & 120 & 120 & 120 & 120 & 120 \\
\hline
\end{tabular}

Source: Author's calculations from EViews 10.0 software

With table 2, we see that the VNI index of the Vietnam stock market has an average value of 584.3180 points. At the time of the highest price index, it reached 1174,460 points, many times higher than the stock index at the lowest time was 245.7400 points. Similarly, for gold prices, there is also a big gap in the last ten years. The consumer price index over the past time has a quite different growth rate with the increase and decrease shown clearly at 0.47 to $4.32 \%$. World oil prices have a big gap, sometimes reaching the highest monthly average value of $\$ 113.7300 /$ barrel, and sometimes falling by only $\$ 33.75000 /$ barrel. The refinancing rate averaged $7.9 \%$ of this value quite far from the highest and lowest interest rates. This shows that in the recent period, the interest rate adjustment is quite a lot, especially after the global economic crisis in 2007 and 2008, the credit market became too hot. Skewness statistics of VNI have a Positive value of 1.186920 shows that VNI has a positive deviation distribution, which is common for emerging stock markets. In the world, most of the distribution of profitability ratios of financial assets has no normal distribution. 


\subsection{Unit root tests}

One of the assumptions of the classical regression model is that the independent Variables must be non-random. If we estimate a time series model where the independent Variables are not stationary, then the assumption of OLS is violated (expectation of mathematics, Variance, and covariance is constant over time) leading to Inefficient $\mathrm{t}$ and $\mathrm{p}$ tests (also called fake regressions). A unit test is a criterion to test Variable is stationary. Dickey-Fuller gave the following inspection criteria:

Ho: $\mathrm{p}=1$ (Variable is not stationary)

$\mathrm{H} 1: \mathrm{p} \neq 1$ (Variable is stationary)

We estimate the model: $t=p / s e(p)$ with distribution according to DF rules

If $|t|>|t \alpha|$ reject the hypothesis Ho. In this case, the Variable is stationary.

Table 3. Unit tests for each Variable

\begin{tabular}{|l|l|l|l|}
\hline \multirow{3}{*}{ Variables } & Test critical values: & \multirow{2}{*}{ P-value } & \\
\cline { 2 - 2 } & -3.486551 & \multirow{2}{*}{ Results } \\
\cline { 2 - 2 } & -2.886074 & & \\
\cline { 2 - 2 } & -2.579931 & & \\
\hline VNI & -9.535877 & 0.0000 & The variable is stationary at first difference \\
\hline SJC & -10.32527 & 0.0000 & The variable is stationary at first difference \\
\hline OIL & -9.065833 & 0.0000 & The variable is stationary at first difference \\
\hline M2 & -11.33129 & 0.0000 & The variable is stationary at first difference \\
\hline EX & -9.553002 & 0.0000 & The variable is stationary at first difference \\
\hline IR & -4.319876 & 0.0000 & The variable is stationary at first difference \\
\hline CPI & -4.476981 & 0.0001 & Variable is stationary at level \\
\hline
\end{tabular}

Source: Author's calculations from EViews 10.0 software

With test results of table 3, we realize that the CPI price index Variable has unit root and stationary at level. The remaining Variables of the original data series (at the level) are non-stationary (or unit roots) when the firstdegree difference has the calculated absolute value more significant than the table lookup value at the significance level 5\% and 10\%. This means that data from VNI Variables, Gold price, oil price, money supply, exchange rate, and interest rate are non-stationary series, the integration level of Variables is 1 or I(1). With purpose avoid false correlation regression, next test is necessary to verify whether there is a co-integration between the Variables in the regression model.

\subsection{Co-integration testing according to VAR method}

When estimating a regression model with Variables that time series is not stationary if the model is co-integrated, then there will be no counterfeiting regression, and standards-based tests of $\mathrm{t}$ and $\mathrm{F}$ are significant because the trend in the chains has eliminated each other. Currently, there are several co-integration testing methods, such as Engle-Granger, Johansen testing, etc. In which, Johansen testing based on a VAR model, including two tests, called trace test and maximum eigenvalue test.

+ Trace test $-\mathrm{H}_{0}$ : the number of co-linked vectors in the system is $\mathrm{r}$, smaller or equal to ro with ro $<\mathrm{p}$ ( $\mathrm{p}$ is the number of Variables in the system); $\mathrm{H}_{1}$ : The impact matrix is synchronous. If the trace test $<$ critical value then accept $\mathrm{H}_{0}$ (not co-integration) and vice versa.

+ Eigenvalue test considers hypothesis $\mathrm{H}_{0}$ is ro co-integration vector for the hypothesis $\mathrm{H}_{1}$ is that there is a ro +1 co-integration vector.

EViews 10 performs co-integration testing according to Johansen's VAR method. This method makes sense when we play time series, not stationary.

Hypothesis $\mathrm{H}_{0}$ : none means there is no co-integration.

Assumption $\mathrm{H}_{1}$ : At most, 1,2,3,4,5 means having a co-relation between the price of gold, interest, consumer price index, exchange rate, oil price to VNI.

To decide to reject or accept $\mathrm{H}_{1}$, we proceed to compare the value of "Trace Statistic" with critical value at the significance level defined in MHM (here we choose 5\%).

- If the Trace Statistic $<$ Critical Value, we accept the $\mathrm{H}_{0}$ hypothesis

- If Trace Statistic $>$ Critical Value, we reject the $\mathrm{H}_{0}$ setting 
Table 4. Co-integration testing according to VAR method

\begin{tabular}{|c|c|c|c|c|}
\hline Hypothesized & & Trace & 0.05 & \\
\hline No. of CE(s) & Eigenvalue & Statistic & Critical Value & Prob. $^{* *}$ \\
\hline None & 0.397851 & $\mathbf{1 6 5 . 8 7 3 2}$ & $\mathbf{1 2 5 . 6 1 5 4}$ & 0.0000 \\
\hline At most $1 *$ & 0.240944 & 107.5395 & 95.75366 & 0.0060 \\
\hline At most 2 & 0.212189 & 75.83636 & 69.81889 & 0.0153 \\
\hline At most 3 & 0.155144 & 48.40914 & 47.85613 & 0.0443 \\
\hline At most 4 & 0.127243 & 29.02144 & 29.79707 & 0.0612 \\
\hline At most 5 & 0.097849 & 13.37015 & 15.49471 & 0.1019 \\
\hline At most 6 & 0.013201 & 1.528198 & 3.841466 & 0.2164 \\
\hline
\end{tabular}

Source: Author's calculations from E-Views 10.0 software

The results in the table show that both tests Johansen and Juselius (1990) provide that the matrix traceability test (trace) and the maximum value control of the matrix (Maxeigenvalue) all claim to have at least one co-integration at 5\% significance level. This proves that there is a healthy long-term relationship (cointegration) between the study Variables. Accurately, we see Trace Statistic $>$ Critical Value, (165.8732> 125.6154) $\Rightarrow$ we reject the assumption $\mathrm{H} 0=>$ meaning the model has co-integration, gold price Variables, oil prices, money supply, price index consumption, exchange rates, and interest rates have a co-relationship with the VNI. This proves that we can perform OLS regression without worrying about fake regression.

\subsection{Select the optimal lag}

The selection of the optimal lag for the model will make by applying the VAR model to the original data series of Variables with a maximum lag of 5. The VAR model will automatically select the optimal lag, based on the standards: Akaike Information Criterion - AIC, Schwarz information criterion - SC and Hannan Quinn information criterion - HQ to select the optimal lag for the model. The optimal lag is determined based on the results consistent with the most standards. Schwarz information standards and information standards HannanQuinn proposed to choose the maximum model lag of 1, meaning the values of the current Variables will be affected by the value of the late Variables as a month earlier.

Table 5. Select the optimal lag for the regression model

\begin{tabular}{|c|c|c|c|c|c|c|}
\hline Lag & LogL & LR & FPE & AIC & SC & HQ \\
\hline 0 & -5240.006 & NA & $1.01 \mathrm{e}+31$ & 91.25227 & 91.41935 & 91.32009 \\
\hline 1 & -4190.254 & 1953.451 & $2.79 \mathrm{e}+23 *$ & $\mathbf{7 3 . 8 4 7 8 9 *}$ & $\mathbf{7 5 . 1 8 4 5 6 *}$ & $\mathbf{7 4 . 3 9 0 4 4}^{*}$ \\
\hline 2 & -4155.670 & 60.14553 & $3.61 \mathrm{e}+23$ & 74.09861 & 76.60485 & 75.11588 \\
\hline 3 & -4109.496 & $74.68137^{*}$ & $3.88 \mathrm{e}+23$ & 74.14776 & 77.82358 & 75.63976 \\
\hline 4 & -4076.280 & 49.67944 & $5.34 \mathrm{e}+23$ & 74.42227 & 79.26767 & 76.38899 \\
\hline 5 & -4028.420 & 65.75521 & $5.87 \mathrm{e}+23$ & 74.44210 & 80.45708 & 76.88355 \\
\hline
\end{tabular}

Source: Author's calculations from EViews 10.0 software

\subsection{Co-integration regression model}

The use of a regression model aims to consider the long-term relationship of independent variables affecting the VNI stock price index. The study uses the p-value to verify whether Variables affect VNI. The results show that SJC gold price, oil price, M2 money supply, exchange rate, and interest rate are statistically significant at $1 \%$ level. Mainly, the consumer price index is not statistically significant. We will conduct further verification to eliminate the consumer price index Variable. 
Table 6. A co-integration regression model with dependent Variable: VNI

\begin{tabular}{|c|c|c|c|c|}
\hline Variable & Coefficient & Std. Error & t-Statistic & Prob. \\
\hline SJC & -0.009110 & 0.002241 & -4.064846 & 0.0001 \\
\hline OIL & 2.921976 & 0.456509 & 6.400697 & 0.0000 \\
\hline M2 & 0.000136 & $1.00 \mathrm{E}-05$ & 13.55233 & 0.0000 \\
\hline IR & 12.64573 & 4.381376 & 2.886245 & 0.0047 \\
\hline $\mathrm{EX}$ & -0.059226 & 0.015919 & -3.720401 & 0.0003 \\
\hline CPI & 11.82328 & 11.30416 & 1.045923 & 0.2978 \\
\hline $\mathrm{C}$ & 1186.240 & 251.8030 & 4.710986 & 0.0000 \\
\hline R-squared & 0.878080 & \multirow{3}{*}{ Durbin-Watson stat } & & \multirow{3}{*}{0.392681} \\
\hline F-statistic & 135.6392 & & & \\
\hline Prob(F-statistic) & 0.000000 & & & \\
\hline
\end{tabular}

Source: Author's calculations from EViews 10.0 software

Looking at the summary table 6 , we can see that $\mathrm{R} 2=0.878080$ indicates that the six macroeconomic Variables affecting the stock price index from the original data explain $87.80 \%$ of changes in the VNI stock price index. This suggests that in addition to being influenced by the above factors, VNI is also affected by other factors such as total industrial production output, trade balance, or herd phenomenon, etc. and VNI stock price index of the previous periods. With an emerging stock market like in Vietnam, the stock index is affected by psychological and asymmetric information, and securities investment is mainly in the form of speculation. This makes the stock price index quite complicated in recent years.

However, with the processed result, for the Consumer Price Index with the elasticity coefficient 11.82328 , however, the value of P-value $=0, .2978>$ the significance level of 0.05 . So the consumer price index is a Variable that is unlikely to affect.

\subsection{Testing of redundant variables}

To verify the inheritance of CPI, we build the following hypothesis:

$\mathrm{H}_{0}: \beta 4=0$ (redundant CPI Variable)

$\mathrm{H}_{1}: \beta 4 \neq 0$ (CPI Variable is not redundant)

The result of processing from table 7 gives us the value Prob $=0.2978>\alpha=0.05$ so we accept the hypothesis $\mathrm{H}_{0}$ means CPI consumer price index, model. The results of model processing after eliminating the consumer price index Variable with R2 $=.876899$ indicate that the model has a significant level of explanation in the rate of $87.68 \%$.

Table 7. Testing of redundant variables

\begin{tabular}{|c|c|c|c|c|}
\hline & Value & $\mathrm{df}$ & Probability & \\
\hline t-statistic & 1.045923 & 113 & 0.2978 & \\
\hline F-statistic & 1.093955 & $(1,113)$ & 0.2978 & \\
\hline Likelihood ratio & 1.156135 & 1 & 0.2823 & \\
\hline Variable & Coefficient & Std. Error & t-Statistic & Prob \\
\hline SJC & -0.009592 & 0.002194 & -4.371670 & 0.0000 \\
\hline OIL & 3.046506 & 0.440891 & 6.909891 & 0.0000 \\
\hline M2 & 0.000135 & $1.00 \mathrm{E}-05$ & 13.50685 & 0.0000 \\
\hline IR & 13.77412 & 4.248223 & 3.242325 & 0.0016 \\
\hline EX & -0.057614 & 0.015851 & -3.634743 & 0.0004 \\
\hline $\mathrm{C}$ & 1172.362 & 251.5567 & 4.660428 & 0.0000 \\
\hline R-squared & 0.876899 & & & \\
\hline F-statistic & 162.4144 & Durbin-Watson stat & & 0.370208 \\
\hline Prob(F-statistic) & 0.000000 & & & \\
\hline
\end{tabular}

Source: Author's calculations from EViews 10.0 software

The implementation of regression after the elimination of the consumer price index Variable made the new model explain the impact of the independent Variables on VNI with a significant level of $87.68 \%$. 


\subsection{Error correction model}

The short-term relationship of the model is taking into account the transient nature of the time being studied and considering the volatility of the stock price index over the month (Variation by month) influenced by Variability. of macroeconomic factors (independent Variables) and the stock price index itself. After determining the results of co-integration between the Variables under study, the ECM was applied to consider the short-term relationship between the Variables. Since the first difference of the Variables is a stop sequence and a lag of one month impact, the study can use OLS technique, adding residuals with t-1 lag are included in the model to ensure long-term relationship system is satisfied.

Table 8. ECM error correction model with the dependent variable: DVNI

\begin{tabular}{|crrrr|}
\hline Variable & Coefficient & Std. Error & t-Statistic & Prob \\
$\Delta$ VNI(-1) & 0.534300 & 0.383087 & 1.394721 & 0.1660 \\
$\Delta$ SJC & -0.000433 & 0.002606 & -0.166203 & 0.8683 \\
$\Delta$ OIL & $\mathbf{1 . 8 4 6 9 9 4}$ & $\mathbf{0 . 5 6 0 1 1 4}$ & $\mathbf{3 . 2 9 7 5 3 4}$ & $\mathbf{0 . 0 0 1 3}$ \\
$\Delta$ M 2 & $7.65 E-06$ & $4.87 \mathrm{E}-05$ & 0.156962 & 0.8756 \\
$\Delta$ IR & $\mathbf{- 1 1 . 6 7 6 6 9}$ & $\mathbf{7 . 0 1 3 0 5 3}$ & $\mathbf{- 1 . 6 6 4 9 9 4}$ & $\mathbf{0 . 0 9 8 8}$ \\
$\Delta$ EX & -0.014206 & 0.017907 & -0.793328 & 0.4293 \\
$\Delta$ CPI & -4.176456 & 6.646297 & -0.628388 & 0.5311 \\
ECM(-1) & -0.441489 & 0.394457 & -1.119233 & 0.2655 \\
C & 2.429976 & 5.010791 & 0.484949 & 0.6287 \\
\hline
\end{tabular}

Breusch-Godfrey Serial Correlation LM Test:

$\mathrm{H}_{0}$ : model does not have a Correlation

\begin{tabular}{|c|c|c|c|}
\hline F-statistic & 0.313725 & Prob. $F(2,106)$ & 0.7314 \\
\hline Obs*R-squared & $\mathbf{0 . 6 8 8 4 8 7}$ & Prob. Chi-Square(2) & 0.708 \\
\hline \multicolumn{4}{|c|}{$\begin{array}{l}\text { Heteroskedasticity Test: Breusch - Pagan-Godfrey } \\
\mathrm{H}_{0} \text { : model does not have Heteroskedasticity }\end{array}$} \\
\hline F-statistic & 0.436761 & Prob. $\mathrm{F}(8,108)$ & 0.896 \\
\hline Obs*R-squared & 3.666635 & Prob. Chi-Square(8) & 0.885 \\
\hline Scaled explained SS & 7.704906 & Prob. Chi-Square(8) & 0.462 \\
\hline
\end{tabular}

Results

Source: Author's calculations from EViews 10.0 software

Looking at the data table 8 , we see: in the short term, the VNI stock price index is affected by oil price factor (5\% significance level) and interest rate factor (10\% significance level).

When other factors remain unchanged, the Variation of oil price increases by $1 \%$, the stock price index will increase by $1.84 \%$. Besides, when other factors do not change the interest rate Variation by $1 \%$, the stock price index will decrease by $11.67 \%$.

Furthermore, the coefficient of correction error (ECM t-1) is -0.441489 but not statistically significant, indicating that the short-term correction rate for long-term equilibrium is slow after the impact shock. Diagnostic tests of autocorrelation and Variance have also shown that the necessary conditions of econometrics on the reliability of regression results are guaranteed.

4.8 Verification of Granger causality

Table 9. Granger causality test results

Source: Author's calculations from EViews 10.0 software

\begin{tabular}{|c|c|c|c|c|}
\hline \multicolumn{4}{|c|}{ Pairwise Granger Causality Tests } & \\
\hline Null Hypothesis: & Obs & F-Statistic & Prob & Results \\
\hline SJC does not Granger Cause VNI & 118 & 0.55984 & 0.5729 & Accept $\mathrm{H}_{0}$ \\
\hline VNI does not Granger Cause SJC & & 0.56173 & 0.5718 & Accept $\mathrm{H}_{0}$ \\
\hline OIL does not Granger Cause VNI & 118 & 2.39439 & 0.0958 & Reject $\mathrm{H}_{0}$ at $\mathrm{p}$-value $10 \%$ \\
\hline VNI does not Granger Cause OIL & & 1.80393 & 0.1694 & Accept $\mathrm{H}_{0}$ \\
\hline M2 does not Granger Cause VNI & 118 & 3.03299 & 0.0521 & Reject $\mathrm{H}_{0}$ at p-value $10 \%$ \\
\hline VNI does not Granger Cause M2 & & 0.75385 & 0.4729 & Accept $\mathrm{H}_{0}$ \\
\hline IR does not Granger Cause VNI & 118 & 3.22846 & 0.0433 & Reject $\mathrm{H}_{0}$ at p-value $5 \%$ \\
\hline VNI does not Granger Cause IR & & 0.05288 & 0.9485 & Accept $\mathrm{H}_{0}$ \\
\hline EX does not Granger Cause VNI & 118 & 0.04648 & 0.9546 & Accept $\mathrm{H}_{0}$ \\
\hline VNI does not Granger Cause EX & & 1.56757 & 0.2131 & Accept $\mathrm{H}_{0}$ \\
\hline CPI does not Granger Cause VNI & 118 & 0.17705 & 0.8380 & Accept $\mathrm{H}_{0}$ \\
\hline VNI does not Granger Cause CPI & & 0.99393 & 0.3733 & Accept $\mathrm{H}_{0}$ \\
\hline
\end{tabular}


Table 9 describes the causal relationship between the Vietnam stock price index and macroeconomic factors with a lag of one month. This result shows that: Vietnam stock index has a one-way causal relationship with the oil price. The M2 money supply is significant at $10 \%$ and with interest rate at $5 \%$ significance level. This proves the fluctuation of oil prices, money supply, and interest rates affecting the variation of the VNI stock price index. Thus, the research results here also almost coincide with the model's test after adjusting the error according to the ECM model.

\section{Conclusion}

From the analytical results, it shown that the data series used in the model except for the consumer price index is stationary at level, the remaining Variables are stationary at first difference, meaning I(1). The co-integration between the Variables found. This is the basis for us to conduct co-integration regression, determine the relationship in the long term. Examine Variables to eliminate unnecessary Variables and little effect on Dependent Variables. At the same time, the model of error correction (ECM) and causality test (Granger) reflects the relationship between Variables in the short term.

In the long term, the results indicate that the VNI stock price index is affected by the following factors: SJC gold price and exchange rate affect negatively on the VNI stock price index. This coincides with the research results of (Hanif \& Bhatti, 2019), (Akbar et al., 2019). Also, oil prices, money supply, and interest rates have a positive impact on the stock price index, which is also consistent with the stock market at Jordanian and Turkey (Tursoy \& Faisal, 2017), (Mohamed \& Ahmed, 2014). The consumer price index Variable is not statistically significant, meaning there is no impact on the stock price index. The removal of the effect of the consumer price index on the stock price index is consistent with the tests.

In the short term, the VNI stock price index positively related to the volatility of oil prices, and the relationship is contrary to the variability of interest rates. Granger causality test also shows that oil prices, money supply, and interest rates are the cause of volatility of the VNI stock price index. However, the verification of the error correction model indicates that the short-term adjustment speed of long-term balance is slow after the impact shocks.

Some of the following main ideas can summarize the findings of the study:

Firstly, adding the world oil price into the model of macroeconomic factors affecting the stock price index. Supplementing the model of studying macroeconomic factors affecting the previous Vietnamese stock market (Hussainey and Khanh Ngoc, 2009), (Vinh, 2014). The fact that the Vietnam stock market is the emerging stock market, as well as the market size, is quite small compared to the market in developed economies, so the stock indexes are affected by Global macro factors are inevitable.

Secondly, the study has analyzed the SJC gold price factor in Vietnam as an independent Variable, which is a critical Variable affecting investors' psychology when investing in the Vietnam stock market. However, so far, there have been no in-depth studies on gold prices affecting the VNI stock price index.

Thirdly, To expand the scope of this study, we can use other factors such as world gold price, world-famous stock price index such as Dow Jones, Nikkei 225, Shanghai Composite Index..., In addition, the impact of macroeconomic factors derived from the company itself, such as earnings per share, seasonal effects, or herd behavior on the Vietnamese stock market can study.

\section{References}

Akbar, M. I., Rauf, A. and Chaudhry, A. F. (2019) 'An Empirical relationship between Macroeconomic Indicators and Pakistan An Empirical relationship between Macroeconomic Indicators and Pakistan Stock Market : 1992-2012', International Journal of Computer Network and Information Security, 18(July 2018), pp. 17-26.

Chittedi, K. R. (2012) 'Do Oil Prices Matters for Indian Stock Markets? An Empirical Analysis', Journal of Applied Economics and Business Research, 2(1), pp. 2-10.

Do, G. Q., Mcaleer, M. and Sriboonchitta, S. (2009) 'Volume 29 , Issue 2 Effects of international gold market on stock exchange volatility: evidence from asean emerging stock markets', Economics Bulletin, 29(2), pp. 599-610.

Francisco, J., Ana, E. and Alberto, C. (2019) 'MACROECONOMIC VARIABLES AND STOCK MARKETS: AN INTERNATIONAL STUDY’, Applied Econometrics and International Development, 13(19-1 (2019)), pp. 43-57.

Gokmenoglu, K. K. (2015) 'The Interactions among Gold, Oil , and Stock Market: Evidence from S \& P500', Procedia Economics and Finance. Elsevier B.V., 25(May), pp. 478-488. doi: 10.1016/S22125671(15)00760-1.

González, M. et al. (2019) 'Macroeconomic Determinants of Stock Market Development', Journal of Applied Economics, 2(1), pp. 29-59. doi: 10.1080/15140326.1999.12040532.

Hanif, M. and Bhatti, A. A. (2019) 'Causality among Stock Market and Macroeconomic Factors: A Comparison 
of Conventional and Islamic Stocks', Journal of Islamic Business and Management (JIBM), 8(2), pp. 1-23. doi: $10.26501 / \mathrm{jibm} / 2018.0802-006$.

Hussainey, K. and Khanh Ngoc, L. (2009) 'The impact of macroeconomic indicators on Vietnamese stock prices’, Journal of Risk Finance, 10(4), pp. 321-332. doi: 10.1108/15265940910980632.

Kaur, H. and Singh, J. (2019) 'Impact of Selected Macroeconomic Variables on Indian Stock Market Index', IBMRD's Journal of Management \& Research, 8(1), p. 1. doi: 10.17697/ibmrd/2019/v8i1/142527.

Kumar, P. and Narayan, S. (2010) 'Modelling the impact of oil prices on Vietnam's stock prices', Applied Energy. Elsevier Ltd, 87(1), pp. 356-361. doi: 10.1016/j.apenergy.2009.05.037.

Mishkin, F. S. (2004) The Economics of Money, Banking, and Financial Markets. seventh.

Mohamed, I. A. and Ahmed, S. (2014) 'The Effects of Macroeconomic Variables on Stock Returns in the Jordanian Stock Market', Global Journal of Management and Business, 3(8), pp. 087-093. doi: 10.4038/suslj.v6i1.1689.

Perera, K. L. . and Silva, S. (2018) 'Macroeconomic Influence on the Stock Market: A Review Influence on the Stock Market: A Review heories on Macroeconomic Influence on Stock Market', International Conference on Business Management, (Icbm), pp. 414-439.

Peter Flaschel, Matthieu Charpe, Giorgos Galanis, C. R. P. and R. V. (2017) 'www.econstor.eu', Bamberg Economic Research Group, Bamberg University, 125. Available at: http://hdl.handle.net/10419/162153.

Sadeghi, J. (2018) 'Dependence between the stock market Middle East', Erasmus School of Economics, (August), pp. 1-42.

Smith, G. (2001) 'T HE P RICE OF G OLD AND S TOCK P RICE I NDICES FOR', FT Personal Finance, (November), pp. 1-36.

Tursoy, T. and Faisal, F. (2017) 'The impact of gold and crude oil prices on stock market in Turkey: Empirical evidences from ARDL bounds test and combined cointegration', ScienceDirect Resources Policy journal. Elsevier Ltd, (25 October 2017), pp. 0-1. doi: 10.1016/j.resourpol.2017.10.014.

Vinh, V. X. (2014) 'An Empirical Investigation of Factors Affecting Stock Prices in Vietnam', Journal of Economics and Development, 16(1), pp. 74-89.

Wei, Y. et al. (2019) 'Oil price fluctuation, stock market and macroeconomic fundamentals: Evidence from China before and after the financial crisis', Finance Research Letters. Elsevier Inc., (20 March 2019), pp. 2-23. doi: 10.1016/j.frl.2019.03.028.

Yang, E. et al. (2018) 'Macroeconomic shocks and stock market returns: the case of Korea', Applied Economics. Routledge, 50(7), pp. 757-773. doi: 10.1080/00036846.2017.1340574. 